\title{
Edward Bond \& the celebrity of exile
}

\author{
Article
}

Accepted Version

Saunders, G. (2004) Edward Bond \& the celebrity of exile. Theatre Research International, 29 (3). pp. 256-266. ISSN 1474-0672 doi: https://doi.org/10.1017/S0307883304000665 Available at https://centaur.reading.ac.uk/31332/

It is advisable to refer to the publisher's version if you intend to cite from the work. See Guidance on citing.

To link to this article DOI: http://dx.doi.org/10.1017/S0307883304000665

Publisher: Cambridge University Press

All outputs in CentAUR are protected by Intellectual Property Rights law, including copyright law. Copyright and IPR is retained by the creators or other copyright holders. Terms and conditions for use of this material are defined in the End User Agreement.

\section{www.reading.ac.uk/centaur}

\section{CentAUR}

Central Archive at the University of Reading

Reading's research outputs online 


\section{EDWARD BOND AND THE CELEBRITY OF EXILE.}

'I would sooner work under a desk lamp with a shade made of human skin at Auschwitz.'[1] This provocative and uncompromising statement from the playwright Edward Bond was made in response to David Hare's and Harold Pinter's acceptance of their honours from the Queen in 1998, and 2002. While Pinter regarded his decision to accept the title Companion of Honour as being 'devoid of any political connotations,'[2] for Bond the motivation behind such actions appeared inexplicable: 'how can people deceive themselves in this way? - how can you write about Socialism out of a mind that would accept such gestures?'[3]

Yet such 'gestures' have important significance. David Marshall, in his book Celebrity and Power, defines celebrity 'as a system for valorizing meaning and communication...convertible to a wide variety of domains and conditions.'[4] The British honour system, with its list of recipients approved by the Prime Minister and Queen, represents acknowledgement of celebrity at an official level by the state. Yet this in turn is a direct reflection of a wider cultural influence, over which state and government have little control. For instance, when The Beatles received their OBE's in 1965, the decision was motivated from the world-wide mass popularity of their music and image rather than from any dictat by the British establishment.

[1]Edward Bond. Letter to author, 15 August 2002.

[2] Michael White. 'Arise Sir Mick, but Pinter takes Surprise top Honour.'Guardian, June 15 2002, p. 17.

[3]Bond. Letter to author 15 August 2002.

[4]David Marshall, Celebrity and Power: Fame in Contemporary Culture ( Minnesota: University of Minnesota Press, 1997 ), p. x. 
Edward Bond's incredulity at his peers being prepared to accept such honours, comes from a writer who has always been suspicious of celebrity culture. Bond's unwillingness to compromise his work to theatrical institutions that seem to pull in the direction of commercial pressures over artistic ones, has seen him since the late 1980s increasingly withdraw from active involvement with mainstream British theatre and embrace a different kind of celebrity in Europe - with his reception in France being a case in point, and a major focus of this article.

Yet the beginnings of Bond's career were marked out by many of trappings of modern day celebrity - namely the controversey that his plays attracted. In the same year that The Beatles were officially recognized and welcomed by the British establishment, Edward Bond's second play at the Royal Court, Saved ( 1965 ) openly challenged it on two fronts. The first of these was the content of the play: Richard Scharine calls it, "the first dramatic self-indictment of the welfare state,'[5] and Saved is an unflattering discourse on how far short of the 'New Jerusalem,' British post-war society had come twenty years on. Second was the way that Saved openly challenged and antagonized the powers of censorship that were still in operation in 1965 and exercized by the Lord Chamberlain's office.

Edward Bond's next play Early Morning ( 1968 ), took this antagonism further. Whereas Saved was returned to the author with requests for the stoning of the baby ( scene 6 ), and the sexually provocative encounter between Len and Mary ( scene 9 ) to be removed; Early Morning was returned with the single infamous comment, 'His Lordship would not allow it.'[6] The Lord Chamberlain's edicts were ignored, and using

[5]Richard Scharine. The Plays of Edward Bond ( London: Associated University Presses, 1975 ), p. 80 [6]Michael Mangan, Edward Bond ( Plymouth: Northcote, 1998 ), p.19. 
a loophole in the law, both productions were put on as Sunday night club performances at the Royal Court. Nevertheless, both plays fell foul of the law. Saved came to court in January 1966, with the magistrate imposing a token fine on the Royal Court for performing the play without a licence. In the case of Early Morning, while the Chamberlain's office managed to obtain a court ruling that required the Arts Council to suspend any subsidies to a theatre producing an unlicensed play, ultimately the authorities failed to successfully impose an outright ban. In the month following the successful prosecution of Saved, a joint parliamentary committee was set up to look at the issue of censorship in the theatre. Their enquiry came to its end while the fate of Early Morning was still being decided by the Department of Public Prosecution, and parliament revoked the Stage Licensing Act of 1843 in September 1968.

It is interesting in the light of correspondence from the Lord Chamberlain's office that the element of Early Morning that seemed to give most offence was Bond's scurrilous depiction of Queen Victoria and her family. Judging by the cryptic minute recorded by the Lord Chamberlain: 'Her Majesty agreed that this [ the plan to prosecute Early Morning ] should be put firmly in the Attorney [ - General's ] lap.' [7] - it is perhaps safe to assume that Edward Bond is unlikely to ever become a recipient on the Queen's honour list...

Saved undoubtedly became a celebrity event in terms of the notoriety it generated; yet while the sensational aspects in its depiction of casual sex and brutal violence were covered by the press in a way we are all too familiar with today, the play is really perhaps better defined as a celebrated event in that it became integral, together with Early

[7] Nicholas de Jongh, Politics, Prudery and Perversions: The Censoring of the English Stage 1901-1968; ( London: Methuen, 2001 ), p.4. 
Morning in ending theatre censorship.[8] The 1969 Edward Bond season at the Royal Court, in which Saved, Early Morning and a new play, Narrow Road to the Deep North, were staged, became simultaneously an event that marked a hard won battle against theatre censorship, as well as being an act of celebration.

Looking back over the critical reception of Saved, despite there being a high degree of outrage and hysteria in the media, [9], there was also an equally strong desire to understand the play. Even a normally conservative newspaper such as the Daily Mail commented, 'it is a muddled and muddling play. But it is certainly a a moral one.'[10] This feeling also manifested itself in sympathetic letters to the newspapers - notably the response from Laurence Olivier [11] - and an organized 'teach in' on the 14 November 1965, at the Royal Court. Chaired by Kenneth Tynan, with Edward Bond and his director William Gaskill in attendance, sympathetic critics and commentators including Mary McCarthy and Ronald Bryden debated the play against less well disposed critics, Irving Wardle and J.W Lambert. This more considered evaluation of the play goes against the received account that Saved provoked widespread shock and alienation form by critics and audiences.

[8]For a detailed discussion of the events see the following: de Jongh, Politics, Prudery and Perversions, pp.214-237; Tony Coult. The Plays of Edward Bond ( London: Methuen, 1979 ), pp.15-17; Malcom Hay and Philip Roberts. Edward Bond: A Companion to the Plays ( London: T.Q Publications ), pp.39-42, 67-9; John Johnston. The Lord Chamberlain's Blue Pencil ( London: Hodder and Stoughton, 1990 ), pp.106-8, 213-16; Scharine, Plays of Edward Bond, pp.18-20, 50-2, 83-6, 124-5, 167-8.

[9]For a wide selection of reviews that appeared at the time see, Philip Roberts ( ed. ), Bond on File ( London: Methuen 1985 ) [10]Peter Lewis. Daily Mail, 4 November 1965. [11]See for instance Penelope Gilliatt, Observer 7 November 1965; Ronald Bryden's review in The New Statesman, 12 November 1965 and Laurence Olivier's letter to The Times 28 November 1965. 
And while the play did provoke outrage in some quarters, it is also true to say that a certain element of myth-making has taken place in regard to those infamous first performances. The Royal Court for instance has a justifiable stake in sustaining its reputation for such celebrated events in its history. As such, stories regarding the critical reception of Saved become blurred. Nicholas de Jongh for instance describes accounts such as those found in William Gaskill's memoirs - ( 'the accumulated bile of the critics was vented on the play and on me for presenting it')[12] - as 'an inaccurate judgement which surrenders to an understandable exaggeration.'[13] It is interesting to compare this more considered treatment of Saved to that of Sarah Kane and her Royal Court debut Blasted ( 1995 ), where in contrast there seemed to be an almost complete unwillingness to critically engage with the play beyond a sense of outrage. It was somewhat ironic that almost exactly thirty years after Saved the one thoughtful and detailed defence and critique of Blasted in the press should come from Bond himself.[14]

The reception of Blasted was also different in that it was the figure of Kane herself - a twenty three year old woman - who became a focus of the play. While this article will explore the recent media construction of Bond as a 'personality' and the reasons in recent years behind his self-styled exile from Britain, in 1965 it was the content and presentation of Saved, rather than speculation about the gender or personality of the writer which fuelled any particular controversy.

[12]William Gaskill. A Sense of Direction (London: Methuen, 1988 ), p.67. [13]De Jongh, p. 220. [14]Edward Bond. 'A Blast at our Smug Theatre' Guardian, 28 January, 1995, p.22. 
However, it is true to say that both Saved and Blasted became celebrity events on their own terms - neither play required hired publicists to artificially produce their celebrity. Celebrated or controversial plays after their initial burst of energy often cool and undergo a process of maturation in which they slowly become incorporated into theatrical repertoire or academic study. For the Royal Court, Edward Bond's Saved, Early Morning, Lear and The Sea, are its equivalents of the crown jewels, which give the theatre a crucial credibility and authority as a centre dedicated to new writing. Of course, Edward Bond is not its greatest find as a 'controversial' or celebrated writer, but follows in a tradition starting obviously enough with John Osborne's Look back in Anger ( 1956 ), to most recently Sarah Kane's Blasted ( 1995 ). The phenomenon of the controversial play is also intimately bound up with the Royal Court's ongoing reputation. Saved was a case in point, in that the play came at a fortuitous point in its history. As Philip Roberts observes, 'though it [ Saved ] played to only $36.7 \%$ for all its twenty four performances, it did rebuild the shaky image of the Court in a quite spectacular way and placed the theatre once more in the centre of controversy.'[15]

The ensuing reputation of Saved and Edward Bond as a dramatist of international stature might have surprised certain commentators at the time. Indeed, from 1965 until 1971 Bond was seen in some quarters as a figure more recognizable to us in the new millennium: that of the public figure whose reputation and profile seem out of proportion to their achievements. Marshall, also defines celebrity as 'a term that announces a vulgar sense of notoriety,' [16], and in 1969 the newspaper critic Herbert Kretzmer remarked that Saved, Early Morning and Narrow Road to the Deep North served as, 'a reminder

[15] Philip Roberts, The Royal Court Theatre 1965-72 ( London: Routledge, 1986 ), p.24. [16] Marshall, p. x. 
that it is possible to become famous for having achieved nothing much at all.'[17] This perception came in part from the plays relative lack of public exposure, and as Michael Mangen has pointed out, up until 1969 'Bond's fame as a playwright was resting largely on the basis of plays which had been banned.'[18]

Nevertheless, Edward Bond took some advantage of the opportunities offered by his new found profile as a controversial young writer from the Royal Court, and between 1966 and 1973 accepted commissions as a screenwriter. This aspect of Bond's career has received scant critical attention from either Theatre or Film Studies. Undoubtedly, much of the reason for this comes from the playwright's own unwillingness to privilege this area of his writing. For instance, Malcom Hay and Philip Roberts in their companion to his plays, [19] were asked by Bond to exclude all screen writing credits from the bibliography of his works. Cynics might argue that the reason Bond played down this aspect of his career was that his work in this medium was not particularly successful. However, by any standards - Hollywood or otherwise - his body of work for film is impressive, with screenplays ranging from Blow-Up ( 1966 ), Walkabout ( 1971 ), Michael Kohlhass ( 1969 ) and Nicholas and Alexandra ( 1973 ). Just as Pinter and Hare's honours could be seen as one of the ultimate celebrity accolades that the British establishment is able to confer, Hollywood did the same for Bond with an Oscar nomination in 1966 for the screenplay of Blow-Up.

[17]Herbert Kretzmer.'Too Deep - Bond's Noh Play.' Daily Express, 20 February 1969, p. 13.

[18]Mangan. Edward Bond, p. 19.

[19]Malcom Hay and Philip Roberts. Edward Bond: A Companion to his Plays ( London: TQ Publications, 1978 ), p.10. 
With such an impressive record Bond could easily have pursued a successful screen writing career, yet he has patently rejected Hollywood in favour of writing for the theatre. In a 1971 letter to Richard Scharine he outlines his rationale for taking on commissions for film work:

I write films in order to live. I've never worked on a film script that interested me deeply -or, if it did, imagined for a moment that one could be allowed to deal with the subject properly. That's why all my serious writing is done for the theatre and it's never interfered with there.[20]

It would seem that the price for working in the medium of film is a willingness to sacrifice a distinctive voice, or take any active role in influencing the finished work within your medium. Certainly in the case of Blow-Up, all the many discussions of the film in books and articles make barely any mention of Bond's contribution. Instead, discussion focuses almost entirely on its director Michelangeo Antonioni's role in the creative process.[21] Given Bond's relative disdain in writing for film, this anonymity might have suited him, but in the case of theatre Bond finds it essential that a platform is given through which to comment on his own work. This necessitates having some form of public profile and access to dissemination through publishing and the media.

While Bond acknowledges that the Royal Court supported him artistically from the early 1960s until the mid 1970s as a writer, he believes that the same situation is no longer true for young dramatists writing today. While Bond chose screen writing to support himself financially for a period, he argues that nowadays theatre exploits and

[20] Cited in Scharine. Plays of Edward Bond, p.159.

[21] See for instance, Ian Cameron and Robin Wood. Antonioni ( London: Studio Vista, 1968 ); John Orr. 'The Camera as Double Vision': Blow-Up to La Belle Noiseuse, in Contemporary Cinema, ( Edinburgh: University of Edinburgh Press, 1998 ), pp. 130-161. The writing credits for Blow-Up in the published text read: 'Screenplay by Michaelangelo Antonioni and Tonino Guerra; English dialogue in collaboration with Edward Bond.' 
then abandons many of its young writers, while simultaneously stuffing their mouths with the illusory glamour of becoming writers for the celebrity driven mediums of film and television

[ Young writers ] are attacked for not using the methods which are in fact destroying theatre and reducing it to the vicious detritus of Hollywood and Broadway - and as I have been invited to write for both places, and as this is a technical matter and not one of judgement, I can speak of it with certainty. So increasingly younger writers are forced to live by writing for the institutions that destroy them. I think this is why Sarah Kane - the best dramatist of her generation - killed herself two years ago. She did this not because she was depressed by criticism and failure. She killed herself because she was faced with success.[22]

Bond calls this nullifying process, 'The Theatre of Symptoms'[23], in which the superficiality of popular culture encourages younger writers to, 'dramatize their despair and frustration but achieve no larger understanding - and so become as tedious as people who constantly tell you about their illnesses.' [24] These writers, lured by the promise of celebrity culture in Bond's view, become essentially reduced to providing what he calls, “"take away services” for tv and stage directors.'[25]

Bond's solution for those dramatists committed to writing innovative theatre is a radical one. In an interview in 1992 he declared: 'writers should go into exile, but in our [ British ] society we send them to the West End instead or to write sitcoms on telly.' [26] This call to 'exile' is indeed the very path Bond has taken for himself, at least in respect to mainstream theatre in this country The reaction to these pronouncements on the

[22]Edward Bond. 'Twenty Three Preliminary Notes on a Committed Theatre.'( Unpublished )

[23] Edward Bond. Letter to author, 28 December 2000.

[24]Edward Bond. Unpublished letter to Lord Alexander, 23 May 2002.

[25]Edward Bond. Letter to author, 28 December 2000.

[26]In an interview Bond comments, 'I was going into exile and it was going to be wonderful.' See Claire Armitstead. 'Flight of the Sparrow,' Guardian, 15 October, 1992, p. 4. 
shortcomings of its venerable theatrical institutions, and many of their well known Artistic Directors has brought about a predictable response. William Gaskill, the director most associated with Bond's work from 1965-1973, believes that since the mid 1970's the plays and the man have increasingly alienated themselves from both the major British stages and their audience.[27] Anthony Jenkins, writing in 1993 also agrees, expressing regret that 'the writer who stood at the vanguard in 1968 seems to have lost his way,' [28].

William Gaskill also expresses scorn over the playwright's self imposed 'exile.' Drawing upon a reference to the figure of the Bard in retirement at Stratford-upon-Avon, who Bond created in Bingo ( 1974 ); he envisages a scenario of his one time colleague in bucolic dotage: 'like Shakespeare, Edward [ Bond ] sits in his garden at Great Wilbraham, with an old gardener and his wife - even if he is not making deals to enclose land.'[29] Gaskill's comments seem to be motivated out of an exasperated sense of affection tempered with regret, in that to his mind Bond has wilfully turned his back on the major stages, yet at the same time has, 'deliberately stopped writing about contemporary life in any direct way.'[30]

While Tony Coult, observing back in 1979 that in Britain, 'the critical climate has consistently stifled any enthusiastic and intelligent response to Bond,'[31] it is possible to identify the key moment when the playwright finally realized that he had finally become estranged from the acting and directing methodology of English theatre. This was the

[27]Gaskill. A Sense of Direction, p.141.

[28]Anthony Jenkins. 'Edward Bond: A Political Education,' in James Acheson ( ed. )

British and Irish Drama since 1960 ( Basingstoke: Macmillan, 1993 ), pp.103-116 ( 114 )

[29] Gaskill, Sense of Direction, p.122

[30]Ibid, p125

[31]Coult, Plays of Edward Bond, p. 9 
RSC production of The War Plays ( 1985 ), which Bond has described as 'a vulgar and in competent travesty'[32]. In a 1985 letter to the director Terry Hands regarding the production, Bond uses the term 'exile' for the first time [33]. Another letter written the following year, to the actress Yvonne Brycleland, in the wake of the experiences at the RSC and subsequent failure of the National Theatre to stage his play Human Canon, see Bond talking pessimistically of the U.K's 'wretched, banal, irresponsible and not even amusing theatre;' yet he also tempers this with the belief that, 'I've finally begun to discover myself as a writer and to know what I want to do.'[34]

This pessimism regarding the state of British theatre, tempered with a growing sense of entering into a new phase in his own writing, seem to be the chief reasons behind Bond's decision to withdraw from its major stages during the late 1980s, that were either unwilling or unable to engage in the demands his work was attempting to make on actors and directors:

I found that if I were bound to this country I could no longer do the work I wanted to do. Theatre here has become restricted. Its methods are increasingly derived from film and television and Broadway...I talk of exile not as a romantic or angry gesture -it is merely the logic of my situation.[35]

[32]Edward Bond. Letter to Dic Edwards 28 April 1986, in Letters II, ed. Ian Stuart ( Harwood Academic Publishers, Luxembourg, 1995 ), p. 97. For a fuller account of the problems in this produciton see Letters II, pp.83-92 and Ian Stuart. Politics in Performance: The Production Work of Edward Bond, 1978-1990 ( New York: Peter Lang, 1996 ), pp.121-146.

[33]Edward Bond. Letter to Terry Hands, 4 December 1985. Letters II, p. 84.

[34] Edward Bond. Letter to Yvonne Bryceland, 17 December 1986. Letters II, p.58.

[35]Edward Bond. Letter to author, 30 June 2003. 
Speaking recently about Edward Bond's estrangement from British theatre, the director Peter Hall believes the pair need one another, [36] but for Bond his past experiences as well as what he observes in the acting, staging and direction of both new and classical plays in this country stand as proof that he is no longer in simpatico with the aims and methodology of current working practice:

All too often directors and actors are content with making my plays "work" - this they do with surface effects such as changes of light and other clichés. They do not want to use the play as coming to a greater understanding of themselves or society...[ My ] work cannot be done in the U.K because the need for it isn't understood. It's like giving eyedrops to the blind.[37]

This in turn produces another shibboleth that regularly arises when British critics and directors comment on Bond's recent work; namely that the playwright stubbornly insists that only he can be sole arbiter in the conception and execution of any given production of his plays. Ruby Cohn's reaction for instance after seeing the 1985 RSC production of The War Plays found in both the writing and Bond's direction, 'an intransigence...[ that ] makes no concessions to the theatre habits of an admittedly bourgeois audience.'[38] While being aware of the shortcomings of this particular production [39] - to the point of publicly withdrawing association from it - Bond argues that his reputation for 'intransigence' is misplaced:

I'm told that I've boxed myself into a corner because I believe only I know how to stage [ my plays ]. This just isn't true. I don't know how to stage them - I have to find out with actors, and I learn a lot from many productions of my plays by foreign directors and from questions and dissertations foreign students send me. I

[36]Peter Hall. Making an Exhibition of Myself ( London: Sinclair-Stevenson, 1993 ), pp. 291-2.

[37]Edward Bond. Letter to author, 16 April 2003.

[38]Ruby Cohn. Retreats from Realism in Recent English Drama ( New York and London: Cambridge University Press, 1991 ), p.85.

[39] Stuart, Letters II, pp. 83-92. 
need a community of people who want to create a new theatre - to begin again from where Euripides stopped. Here, [ the U.K ] Euripides is probably the name of a soft drink.[40]

The other response employed in Britain when it comes to Edward Bond is to pretend that, metaphorically at least, he is dead; so that while for instance in France he is equally well known for newer work such as The War Plays and Coffee ( 1995 ), back in his home country Bond is most associated with work produced in the period from Saved to The Sea. If newer plays are ever discussed, such as Chair ( 2000 ), they are either seen as 'oblique' or 'minor Bond'[41]. This effectively amounts to embalming the playwright through canonization. Saved for instance is required reading on almost any British university course concerned with its post-war drama, yet this gives Bond's work the kind of celebrity accorded to dead playwrights like Ibsen and Shaw, rather than providing an introduction and engagement to the more challenging task of assessing current work in the light of the old. While David Ian Rabey in his recent survey of British drama from 1940 believes that the recent play Coffee, 'represents a new dynamism in Bond's work,' [42] institutionalizing him in this way means that older work can be nicely tamed for academic study and newer plays ignored altogether.

Of course, part of this relative anonymity in Britain has been at Bond's own doing, in that he often refuses to allow his work to be produced by its major theatres.[43] His rationale for example in rejecting back in 2000 permission for The National Theatre to stage The Fool ( 1975 ) was succinct and brutal: 'You cannot do My Fair Lady one day

[40]Edward Bond. Letter to author, 30 June 2003.

[41]Logan. Guardian, 5 April 2000.

[42]David Ian Rabey. English Drama Since 1940 ( London, Pearson 2003 ), p.85

[43]The Young Vic (2000), The Almedia ( 2002 ) and The Royal Court ( 2003 ) all approached Bond to stage productions of Saved. All theatres were refused permission. 
and Macbeth the next: you cannot be Van Gogh one day and paint green-faced oriental ladies the next. You have to choose, and if you don't what you do chooses you.'[44] This also extends to commissions for new work, where despite being approached recently by RSC Bond has politely declined.[45]

While in Britain Edward Bond has been given the role of a brooding exiled Napoleonic figure in a rural Cambridgeshire equivalent of the island of Elba - directionless and without a theatre or an audience, the real situation is very different. For Bond, exile has paradoxically meant gaining a new freedom and new appreciative audiences. Since the mid 1990s a renewed and sustained interest in his work has taken place in Europe, and especially France where he is accorded a very different kind of celebrity.

While his plays have always been regularly performed throughout Europe since the 1960s, this new relationship with French theatre is of some note. The key event that began the process was the success of The War Plays ( Pieces de Guerre) in 1995 staged at the Odeon- Theatre De L'Europe in Paris. While its British premiere was described by Ruby Cohn as 'too long to sustain a drama'[46], Michael Mangan comments, 'In France it was described as the most important play written since the Second World War.'[47]

Similarly, In the Company of Men, dismissed by Anthony Jenkins when it was first presented in this country as 'a rambling, self indulgent account of post-modern society,' [48] was a critical and commercial success in France, culminating in the play currently

[44] Edward Bond. Letter to author, 24 July 2000.

[45]Edward Bond. Unpublished Letter to Paul Sirrett 15 November 2002.

[46]Cohn, Retreats from Realism, p.84.

[47] Mangan, Edward Bond, p.86.

[48]Jenkins, 'Edward Bond: A Political Education,' p.114. 
being adapted for film project in a psuedo-documentary style, similar to Al Pacino's exploration of Shakespeare's Richard III in Looking for Richard ( 1996 ).

Although Brian Logan sees the success in France as 'part of the Bond myth,'[49] such is the appetite for his work in France, that even a play such as Existence ( 2002 ), which was originally written for medium of wireless was performed in the same year as a stage play in Paris.[50]

Bond's 'exile' in France has also seen a constructive relationship forged between director Alain Francon, and the Theatre du la Colline in Paris; and is reminiscent in some respects of the William Gaskill / Royal Court partnership from 1962-1973. Just as Bond has appreciated this nurturing interconnection during his early career as a writer, he feels that the relationship with France has allowed him to develop a new phase in his writing:

I feel I am entering a new 'site' of drama...and what I've been doing in the past decade [the 1990s ], is exploring and discovering this...my alienation from the U.K theatre has served me well because I could not understand this if I had to work here.[51]

Just as Peter Brook - another well known British theatrical exile - has found Paris to be a productive enviroment which actively encourages and supports his experiments into the nature of acting and theatre practice, the same situation is also true of Edward Bond. He comments: 'In France there is a growing pressure on me to explore / demonstrate modern theatre and lead actors, and I find the readiness and general atmosphere

[49]Brian Logan, 'Still Bolshie after all these years.' Guardian, 5 April 2000, p.7. [50]Recent productions include Saved and The Woman (Champs Elyses, Paris, 2000 ); At the Inland Sea ( Colline, Paris 2000 ); Human Canon ( Marseilles, December 2000 ); Lear ( Vallence, 2000 ); Eleven Vests ( Alfortville 2001 )The Crime of the Twenty First Century ( Colline, Paris 2001 ); The Children ( Paris 2002 ).Coffee, The Crime of the Twenty-First Century and a new play are due to be presented in Paris 2003 as The Colline Trilogy.

[51]Letter to author, 22 January 2000. 
conducive to good work.' [52] This has proved to be a pleasing development for a playwright who while working in Britain had come to be increasingly frustrated by the tradition of limited rehearsal time severely restricting any chance to practically explore the structure and ideas of his work. Since 2002 in France and Belgium, Bond has been invited to conduct a series of acting and directing workshops. While in the past he has intermittently developed an understanding of his own work and drama in general through practical experimentation with actors - notably in the workshops conducted in 1992 with Cicely Berry at the RSC [53], and his time spent during 1982-3 at the University of Palmero Italy as Visiting Professor [54] - the workshops in France have produced a major new development in his ongoing ideas about drama, or Theatre Events ( T.E's ) as her terms them. Four one hour programmes of these acting classes have been screened on French television, and a forthcoming book by Bond, provisionally entitled The Invisible Object promises to be an important evaluation of the work he has conducted with the actors. In a recent letter to Paul Sirrett, the RSC's resident dramaturg Bond comments, 'we need a theatre for our time and I think I have my sights on it.' [55]

Yet, compared to playwrights such as Harold Pinter, Tom Stoppard and David Hare, Bond has a far lower public profile as an immediately recognizable figure or personality. Part of this comes from the fact that despite also having a reputation for being 'serious'

[52]Letter to author, 15 October 2002.

[53]Details of some of this work can be found in Cicely Berry. Text in Action: a definitive Guide to Exploring Text in Rehearsal for Actors and Directors ( London: Virgin Publishing, 2001 )

[54] An important development in Bond's ideas about acting is what he calls, 'The Palermo Paradox / Improvization.' For details on this see the following: Edward Bond. 'Commentary on the War Plays.' The War Plays ( London: Methuen, 1991 ), p.247 ). Also, Ian Stuart, ed. Selections from the Notebooks of Edward Bond. Volume II ( London, Methuen 2002 ), pps.218, 224

[55]Edward Bond. Unpublished Letter to Paul Sirrett, 15 November 2002. 
dramtists, Pinter, Stoppard and Hare have all succeeded in managing to attract West End and Broadway audiences. The composition of Bond's audiences have always been more uncertain. In a letter to Adrian Noble in 1988 concerning his work at the RSC, Bond showed an acute awareness of the problem:

The trouble is that when someone does one of my plays they're doing me a favour. If you do an Ayckbourn or a Stoppard they're doing you a favour. If you do an Ayckbourn or a Stoppard they'll make money for you: I merely offer people that self-respect which comes from the fear of the self.[ ${ }^{56}$ ]

Part of Bond's reticence at becoming a playwright with a high public profile also seems to be based on his suspicions that access to the channels that promote celebrity can lead to a form of self-aggrandizement. For instance, in a letter, Bond recounts rehearsing Shakespeare's Richard III with the actor Al Pacino for his film Looking for Richard, but turned down the opportunity to actually appear: 'I don't like myself on film, it's too exhibitionist.'[57] Bond seems more content to let his writings speak for him, than become their visible spokesman. He is also willing to do interviews for the British media, but is wary of both their reactions to him and their actual knowledge of his work: 'I'm used to be being interviewed by French and other foreign journalists - who are informed, if not about me then at least about a few things that have happened in the last hundred years.' When asked in 2000 by the broadcaster John Tusa for an hour long wireless interview Bond agreed ( although ultimately unhappy with its content and subsequent

$\left[{ }^{56}\right]$ Bond, Letters II, p.59.

[57]Edward Bond. Letter to author, 22 January 2003. 
refusal to have the interview published ) [58], 'because it would be a chance to talk at length and go beyond sound-bites.'[59]

Misrepresentation is all part of the apparatus of celebrity. The popular British media like to cast figures - whether they are willing or not - into a certain mould, so David and Victoria Beckham undergo transmogrification into 'Posh and Becks,' and become defined by whatever yardsticks and peccadillos newspaper editors and television producers wish to define for them. The same process also takes place, albeit in a far more low key manner, with well known dramatists. A case in point is the media construction in recent years of Harold Pinter. Harry Derbyshire observes that British responses seem more concerned with turning the playwright into, 'a comic character than a living individual, a device with which to amuse their readers and themselves.' [60] So, Pinter becomes the following: a naive critic of American foreign policy [61]; an egotist who wants the Comedy Theatre in London renamed The Harold Pinter Theatre [62], or calls out the entire West London constabulary to look for his car [63].

Bond's personality in the media is manipulated differently, whereby along with Arnold Wesker and Peter Nichols he has often in recent years been cast in the role of embittered curmudgeon, or 'Ghost of Theatre Past,' rattling his chains and railing at British theatres and their Artistic Directors for their lack of vision and failure to stage his new work.

[58] John Tusa, ed. On Creativity ( London: Methuen, 2003 )

[59]Edward Bond. Letter to author, 28 December 2000.

[60]Harry Derbyshire, 'Pinter as Celebrity,' in The Cambridge Companion to Harold

Pinter ed. Peter Raby ( Cambridge: Cambridge University Press, 2001 ), pp. 230-245

( p.234. )

[61]Michael Wood, 'Nice Guy,' London Review of Books, 14 November 1996, p. 11. [62] Robert Yates. 'Diary,'Observer, 15 November 1998, p. 4.

[63]Michael Coveney. 'Harold Pinter, Playwright and Player: Dramatic Persona.' Observer, 29 September 1996, p.20. 
While the media seem to enjoy forcing this role onto him, Bond's recent work and its reception in France shows this to be a gross misrepresentation of him. His response to the 'angry old man' tag has been one of bemusement. For instance, in 1994 he responded to the journalist Georgina Brown's newspaper article which used the epithet [64].

I last had a new play [ Summer ] professionally staged over here [ the UK ] over twelve years ago. Yet critics seem strangely obsessed with me - there seems almost a ritual need to abuse. Why? Why don't you forget me? We are now no bother to each other. I'm very happy with what I'm doing and my good fortune still surprises me.[65]

In another letter, to Max Stafford-Clark, Bond upbraids the director for believing the media construction of him, 'retreating into some country hermitage like the tramps in The Pope's Wedding.'[66]

The allusion Bond draws to public perception moulding him into one of his own fictional creations is not so far removed from Harold Pinter's recognition that the gap between 'a fictitious version of me'[67], has been reconstituted from jumbled elements of his other public personas. Bond also recounts a similar division:

Once a stranger in a shop said to me, 'are you Edward Bond?' - and coming out of a reverie on something I said, 'I'm not sure.' The stranger became cross. I hadn't meant to be difficult. I was just looking at the question from a slightly different angle than the questioner intended - am I the person who writes or, really, the person who weeds?[68]

[64] See for instance, Georgina Brown. 'Angry old men of the Theatre.'Independent, 2 November, 1994, p.22.

[65] Edward Bond. Letters. Volume IV, ed. Ian Stuart ( Amsterdam: Harwood, 1998 ) p. 72.

[66]Bond. Letters II, p. 133.

[67]James Rampton. 'Music to his ears.' Independent, 17 April 1999, p.45.

[68]Edward Bond. Letter to author, 22 January 2003. 
If celebrity is an unstable and uncontrollable force for its recipient, Edward Bond seems largely to be in comfortable equilibrium with it. Even in Britain, he has access to most forms of media when he so requires. Bond's ongoing collections of published letters, articles and notebooks, with the latter alone constituting what Carl Miller believes to be, 'an aesthetic more detailed than any other theatre practitioner in this country has attempted,'[69] suggest someone who can escape many of the compromises celebrity brings.

There are also signs of a wary rapprochement with Britain. Two new wireless plays, Chair ( 16 March 2001 ) and Existence ( 2 February 2002 ) have been broadcast on BBC Radio 4, together with a revised production of In The Company of Men, broadcast in May 2003. The National Theatre Studio staged a private production of Lear in June this year with Roger Allam in the title role, and Bond still writes for the Birmingham based theatre in education group Big Brum. It is also untrue to say that Bond has ceased to care about the major British theatres in which he used to have his work staged. For instance, during the period of transition in 2002 at the RSC following the announcement that its Artistic Director Adrian Noble was leaving Bond wrote a long letter to its chairman Lord Alexander about the theatre's future - outlining its problems as well as offering remedies [70].

For Bond it is the utilitarian purpose and the very need to which both his own work and drama in general can be put to, rather than considerations based around prestigious

[69]Carl Miller. 'Theatre begins at the Gates of Auschwitz and if you don't know what I'm Talking about then I'm Wasting my Time.' Independent, 21 May 1997, p. 4. [70]Edward Bond. Unpublished letter to Lord Alexander, 23rd May 2002. 
venue or 'star casting.' Two recent incidents that Bond himself recalls help to make this

clear. One took place at a recent acting workshop he conducted in Marseilles, France:

I worked - in addition to the adult workshops - with immigrant children from the poorer parts. A few years ago these parts were communist - the former dwellers now vote National Front - and at a public discussion someone asked me 'why do you work with such riffraff?' - and I knew it was the place where I should be. Is it really supposed that I would be tempted by a West End or Broadway transfer?[71]

The second incident refers to a visit Bond made to see the students of Varn Dean College in Sussex, who had staged an adaptation of his prose piece Fables [72]. In a letter to the teacher and cast Bond explained, 'how important an occasion such as this is to me. I sometimes see performances in large theatres and afterwards feel irritated and saddened that what I had written could be used in such a cheap and distorted way.'[73] Bond's appearance at this performance by a group of sixth form students again underlines his commitment to the staging of his work based on the degree to which it has intrinsic worth over that of surface glamour and the culture of celebrity.

[71]Edward Bond. Letter to author, 30 June 2003. [72]Contained in Plays 7 ( London: Methuen, 2003 ), pp.365-405. [73]Edward Bond. Unpublished Letter to Aine King, 5 April 2003. 